\title{
Emlőelváltozások multidiszciplináris értékelése és ennek eredményei a Decker-féle korrelációs rendszer ötéves tapasztalatai alapján
}

\author{
Cserni Gábor dr. ${ }^{1,2}$ - Ambrózay Éva dr. ${ }^{3}$ - Serfőző Orsolya dr. ${ }^{3}$ \\ ${ }^{1}$ Bács-Kiskun Megyei Kórház, Patológiai Osztály, Kecskemét \\ ${ }^{2}$ Szegedi Tudományegyetem, Általános Orvostudományi Kar, Szent-Györgyi Albert Klinikai Központ, \\ Patológiai Intézet, Szeged \\ ${ }^{3}$ Mamma Zrt., Emlődiagnosztikai Egység, Kecskemét
}

\begin{abstract}
Bevezetés: Az emlőbetegségek képalkotó diagnosztikája során felfedezett elváltozások gyakran mikroszkópos vizsgálatot igényelnek. A jelenleg érvényes ajánlások szerint a radiológiai, fizikális, citológiai és hengerbiopsziás eltéréseket öt kategória egyikébe kell osztályozni. A Decker-féle rendszer ezeken felül a klinikai észlelés és a patológiai értékelés egymásnak való megfelelésének és a további teendőknek az osztályozását is magában foglalja.

Célkitüzés: Beszámolni a Decker-féle rendszer multidiszciplináris emlőbizottságunkban való alkalmazásának első ötéves eredményeiról.

Módszer: Retrospektív elemzés a 2010-2014 között emlőbetegség miatt operált, illetve ugyanezen periódusban az emlőbizottság előtt megjelent betegek dokumentációja alapján.

Eredmények: Az 1716, kezelés előtti bizottsági megbeszélésre kerülő eset közül 1531-ben nonoperatív diagnosztika tisztázta a felfedezett eltérések mibenlétét, 157 esetben azonban diagnosztikus kimetszésre volt szükség; 1122 eset (65\%) bizonyult malignusnak. A citológia használata ellenére, a malignitás kórismézése 69\%-ban hengerbiopsziából származott. A nem sebészi megközelítés 14 esetben sikertelen, téves vagy késedelmes volt.

Következtetés: Az emlőelváltozásokat multidiszciplináris környezetben kell értékelni. A Decker-féle rendszer alkalmas a radio- és klinikopatológiai korreláció és az ennek függvényében végzendő további teendők kodifikációjára és elemzésére.

Orv Hetil. 2017; 158(28): 1100-1108.
\end{abstract}

Kulcsszavak: emlő képalkotó diagnosztika, emlőrák, emlőrákszűrés, multidiszciplináris kommunikáció

\section{Five-year experience with the multidisciplinary evaluation of breast lesions according to the Decker radio-pathologic correlation system}

\footnotetext{
Introduction: Lesions identified during breast imaging often require microscopic verification. Current recommendations imply the classification of radiological, clinical, cytology and core biopsy findings into one of five predefined categories. The Decker system also includes a classification of both the correlation between radiology and pathology and the actions required on this basis.

Aim: To report on the five-year results of the implementation of the Decker system in our pretreatment multidisciplinary breast team.

Method: Retrospective analysis of patients operated on because of breast diseases or appearing at the multidisciplinary breast team during the period between 2000 and 2014 .

Results: Of 1716 cases discussed, 1531 were solved by non-operative diagnostics, 157 required diagnostic excisions; 1122 cases $(65 \%)$ proved to be malignant. Malignancy was diagnosed by core needle biopsies in $69 \%$ of the cases. The non-operative approach was unsuccessful, delayed or wrong in 14 cases.

Conclusion: Breast lesions need to be evaluated in a multidisciplinary setting. The Decker-system is suitable for the recording and analysis of the correlation between radiologic/physical and microscopy findings, and of the ensuing diagnostic/therapeutic actions.
} 
Keywords: breast cancer, breast cancer screening, breast diagnostic imaging, multidisciplinary communication

Cserni G, Ambrózay É, Serfőző O. [Five-year experience with the multidisciplinary evaluation of breast lesions according to the Decker radio-pathologic correlation system]. Orv Hetil. 2017; 158(28): 1100-1108.

(Beérkezett: 2017. április 18.; elfogadva: 2017. május 18.)

\section{Rövidítések}

$\mathrm{A}=\mathrm{a}$ Decker-féle rendszer cselekvésre (akció) vonatkozó kategóriáinak betújele; $\mathrm{ADH}=$ atípusos ductalis hyperplasia; $\mathrm{B}=\mathrm{a}$ Decker-féle rendszer és a hazai/európai ajánlás hengerbiopsziás minták (biopszia) értékelésére vonatkozó kategóriáinak betüjele; BI-RADS ${ }^{\circledR}=$ Breast Imaging-Reporting and Data System (az American College of Radiology emlő képalkotó diagnosztikára bevezetett osztályozási és adatgyújtési rendszere); $\mathrm{C}=$ a Decker-féle rendszer és a hazai/európai ajánlás citológiai minták értékelésére vonatkozó kategóriáinak betújele; $\mathrm{Co}=$ a Decker-féle rendszer korrelációra vonatkozó kategóriáinak betúijele; DCIS = ductus carcinoma in situ; EIC = extenzív intraductalis komponens; IDP = intraductalis papilloma; ILC = invazív lobularis carcinoma; $\mathrm{K}=$ a hazai ajánlás fizikális vizsgálat (klinikai) értékelésére vonatkozó kategóriáinak betűjele; $\mathrm{LG}=$ low grade (jól differenciált); MRI = mágneses rezonanciás képalkotás; NST (IDC) = nem speciális típusú emlőrák (invazív ductus carcinoma); OCI $=$ (overall clinical impression $)$ összesített klinikai benyomás - a Decker-féle rendszer képalkotókkal és fizikális vizsgálattal nyert információk összesítésén alapuló kategóriáinak a betűjele; $\mathrm{R}$ = a Decker-féle rendszer és a hazai ajánlás mammográfiás vizsgálat (radiológia) értékelésére vonatkozó kategóriáinak betújele; SD = szelektív ductectomia; $U$ = a Decker-féle rendszer és a hazai ajánlás ultrahangvizsgálat értékelésére vonatkozó kategóriáinak betűjele

Az emlőrák a nők leggyakoribb rosszindulatú megbetegedése, amely a terápiás eredmények ellenére, gyakorisága miatt, a daganatos halálozásban is jelentós [1]. A mammográfiás emlórákszűrés a betegséget korai stádiumban segít felfedezni, és ezzel a mortalitást is csökkenti $[2,3]$. A mammográfia kapcsán észlelt elváltozásokat a világ számos országában az American College of Radiology úgynevezett BI-RADS ${ }^{\circledR}$ rendszere szerint sorolják be, aszerint, hogy milyen kockázata van annak, hogy az elváltozás emlőrák legyen [4]. Magyarországon a szervezett emlőrákszúrést 2002-ben vezették be [5], protokollja szerint a mammográfiás képet a BI-RADS ${ }^{\circledast}$ rendszerhez hasonló, de azzal nem azonos és kevésbé jól meghatározott öt kategóriába (Rl-R5) kell besorolni (1. táblázat) $[4,6]$. Párhuzamosan az ultrahang- (U) és a fizikális vizsgálat $(\mathrm{K})$ eredményei is ezzel analóg módon sorolandók öt kategóriába [4]. A képalkotókkal és/vagy fizikálisan észlelt elváltozások jelentôs része patológiai verifikációt igényel, ami lehetőleg nonoperatív diagnosztikával, aspirációs citológiával vagy hengerbiopsziával történik [7], de ezek elérhetetlensége, alkalmatlansága esetén a sebészi kimetszés, az excisiós biopszia ma is egy élő alternatíva, amelyet a lehető legritkábban szabad használni. A narkózisban végzett, a beteg számára megterhelő és egyben költségesebb sebészi biopsziára (surgical biopsy, open biopsy) csak a minimálisan invazív komplex emlődiagnosztika lehetőségeinek kimerülése után szabad, hogy sor kerüljön; a nonoperatív diagnosztikának ugyanis pontosan az az egyik célja, hogy szükségtelenné tegye a sebészi biopsziákat. A jelenlegi ajánlások az említett patológiai verifikációs lehetőségek eredményeit is öt kategóriába javasolják besorolni (1. táblázat) [7]. Az egy-egy elváltozásról így nyert információkat multidiszciplináris közegben kell értékelni [7], és így javasolt eldönteni, hogy milyen további teendők szükségesek. A döntéseket követhetően és világosan kell dokumentálni. Erre több lehetőség is adódik. Intézményünkben az írásban rögzített vélemények mellett a Decker által javasolt értékelési rendszert adaptálva történik ez az értékelés $[8,9]$. Jelen közleményben ennek első ötéves tapasztalatairól számolunk be.

\section{Betegek és módszer}

Az emlőrákszűrés kapcsán a malignus elváltozások azonosítására törekszünk. Ugyanakkor intézményünkben a benignusnak tűnő elváltozások jóindulatú voltának igazolására is történnek mintavételek, mivel ezen verifikáció után a nők megnyugtatóan visszakerülhetnek a koruknak és az ajánlásoknak megfelelő szưrési gyakorlatba, sebészeti beavatkozásra általában nincs szükség, kivéve, ha az elváltozás mérete és/vagy a beteg kívánsága azt mégis indokolja. A Decker-féle rendszert (1. táblázat) kifejezetten a szûrésben kiemelt elváltozások értékelésére dolgozták ki. Gyakorlatunkban nemcsak szúrésből kiemelt esetek értékelésére használtuk módosított változatát, hanem minden olyan esetre, ahol mikroszkópos vizsgálatra mintavétel történt. Kivételt mindössze a komplikáció nélküli ciszták jelentettek, mert ezekből az aspirációs minták nagy része nem került multidiszciplináris megbeszélésre a (C2) citológiai vizsgálat ellenére, ami összhangban van azzal a gyakorlattal, hogy ezek a minták nem is kell, hogy szükségszerúen mikroszkópos vizsgálatra kerüljenek [10].

Eredetileg az értékelési rendszer alapja a Magyarországon széles körben nem használatos, de opcionálisan javasolt BI-RADS ${ }^{\circledR}$ szerinti képalkotó értékelés, és a mintavételek is kizárólagosan hengerbiopszia vagy vákuumasszisztált biopszia formájában szerepelnek benne. A BI- 
1. táblázat |A módosított Decker-féle rendszer egyes elemeinek kategóriái és értelmezésük

\begin{tabular}{|c|c|c|c|c|c|}
\hline $\begin{array}{l}\text { Kategória neve/ } \\
\text { besorolás }\end{array}$ & 1 & 2 & 3 & 4 & 5 \\
\hline $\mathrm{R}$ & Negatív/nem kóros & Benignus & Bizonytalan, valószínúleg benignus & Malignitásra gyanús & Malignus \\
\hline $\mathrm{K}$ & Negatív/nem kóros & Benignus & Bizonytalan, valószínúleg benignus & Malignitásra gyanús & Malignus \\
\hline $\mathrm{U}$ & Negatív/nem kóros & Benignus & Bizonytalan, valószínúleg benignus & Malignitásra gyanús & Malignus \\
\hline OCI & Negatív/nem kóros & Benignus & Bizonytalan, valószínúleg benignus & Malignitásra gyanús & Malignus \\
\hline $\mathrm{C}$ & Elégtelen & Benignus & Atípusos, valószínúleg benignus & Malignitásra gyanús & Malignus \\
\hline B & $\begin{array}{l}\text { Szabályos } \\
\text { emlószövet/ } \\
\text { értékelhetetlen minta }\end{array}$ & Benignus elváltozás & $\begin{array}{l}\text { Bizonytalan malignitási potenciálú } \\
\text { elváltozások (malignitáshoz } \\
\text { valamivel gyakrabban }(=<25 \%) \\
\text { társuló elváltozások meghatározott } \\
\text { csoportja) }\end{array}$ & Malignitásra gyanús & $\begin{array}{l}\text { Malignus laesio; } \\
\text { B5a: in situ } \\
\text { carcinoma, B5b: } \\
\text { invazív carcinoma, } \\
\text { B5c: bizonytalan } \\
\text { invazivitású } \\
\text { carcinoma, B5d: } \\
\text { egyéb malignitás }\end{array}$ \\
\hline $\begin{array}{l}\text { Co } \\
\text { (OCI és C vagy } \\
\text { B korrelációja) }\end{array}$ & Korreláció & Korreláció hiánya & $\begin{array}{l}\text { Bizonytalan korreláció: } \\
\text { 3a valószínú; } \\
\text { 3b valószínütlen }\end{array}$ & - & - \\
\hline A & $\begin{array}{l}\text { Nincs diagnózis } \\
\text { (ismételt biopszia) }\end{array}$ & $\begin{array}{l}\text { Benignus diagnózis } \\
\text { (szűrési protokoll } \\
\text { szerinti } \\
\text { utóvizsgálatok) }\end{array}$ & $\begin{array}{l}\text { Benignus némi bizonytalansággal } \\
\text { (rövid távú követés) }\end{array}$ & $\begin{array}{l}\text { Kockázatot jelentő } \\
\text { laesio (további } \\
\text { vizsgálat szükséges) }\end{array}$ & $\begin{array}{l}\text { Malignus laesio } \\
\text { (kezelése } \\
\text { tervezhetó) }\end{array}$ \\
\hline
\end{tabular}

RADS $^{\circledR}$ rendszer szerinti értékelés hiányában a magyar szürési protokollban ajánlott besorolást kellett használnunk, és ezeket az eredményeket használtuk fel a klinikai gyanú kategóriájának meghatározásakor. Ennek értelmében a mammográfia $(\mathrm{R})$, az ultrahang $(\mathrm{U})$ és a fizikális vizsgálat $(\mathrm{K})$ kategóriái közül a legmagasabb értékű határozza meg az összesített klinikai benyomás kategóriáját (overall clinical impression - OCI), amely a „nincs elváltozás” l-es kategóriájától a malignitás 5-ös kategóriájáig terjed (1. táblázat). Tekintettel arra, hogy Magyarországon, így intézményünkben is, az aspirációs citológia az első megközelítés sok laesio esetén, a nonoperatív patológiai diagnosztikai besorolásban ennek eredményeit is figyelembe vettük. A rendszer további lényeges eleme a radio- (kliniko-) patológiai korreláció értékelése. Ennek kapcsán a multidiszciplináris értékelésben részt vevők azt vizsgálják, hogy a minta megfelelhet-e a klinikailag és/ vagy képalkotóval detektált elváltozásnak. Szemléltetésként, ha minden szövethengerben ugyanaz a benignus elváltozás látható (például szklerotizáló adenosis), a mintavétel tisztázhatóan megfelelő helyről történt, akkor a benignus patológia nagy biztonsággal megfelel a vizsgált elváltozásnak (Col). Ugyanakkor, ha a hengerbiopsziák nagy része szabályos emlőállományt mutat, az egyik henger kis részében felismerhető egy benignus laesio (például ugyanaz a szklerotizáló adenosis), akkor hasonló korreláció nem állítható fel ( $\mathrm{Co} 2$ vagy $\mathrm{Co} 3)$, annak ellenére, hogy a diagnosztikus kategóriák lényegében azonosak. A megfeleltethetőség vizsgálatakor tehát a klinikai, radiológia és patomorfológiai megjelenés mellett a mintában jelen lévő elváltozások mennyisége is figyelembe veendő. A korreláció megléte (Col) és hiá- nya (Co2) mellett a korreláció bizonytalansága (Co3) is szerepel az értékelési rendszerben. Ezek függvényében határozható meg a további teendők köre, az A (akció) kategória (1. táblázat).

A fentiek szerint módosított Decker-rendszert tehát a multidiszciplináris kezelés előtti emlőbizottsági megbeszéléseken a mintavétellel járó esetek értékelésére használjuk. Az értékelés során egy beteg egyoldali elváltozásai egy esetként, a legmagasabb kategória alapján kerültek feldolgozásra, függetlenül attól, hogy hányszor kerültek az elváltozások teammegbeszélésre. Az ellátási tervben a multiplex elváltozások szükség szerint elkülönítve szerepeltek, de ez az adatok elemzését nem befolyásolta. Egy beteg kétoldali elváltozásai oldalanként külön esetnek számítottak, akárcsak a vizsgált időszak alatt újként jelentkező elváltozások (például malignus laesio miatt lezárt, kezelt esetben később kialakuló új eltérés). Egyes teammegbeszéléseken tárgyalt eseteknél a patológiai mintavétel nem intézményünkben történt, a hozott eredményeket vettük figyelembe, és előfordult, hogy a mintavételt követő beavatkozás sem nálunk volt, de ezeket az eseteket sem zártuk ki az elemzésből.

A közleményben a módszer 2010 januárjában történő bevezetésétől az első öt év eredményeinek elemzését és tapasztalatait mutatjuk be.

\section{Eredmények}

2010. január és 2014. december között, Kecskeméten, a Bács-Kiskun Megyei Kórházban, a munkaszüneti napok miatt 233 (évente 46-48), heti rendszerességgel megtartott teammegbeszélésen 1716 patológiai vizsgálatra 


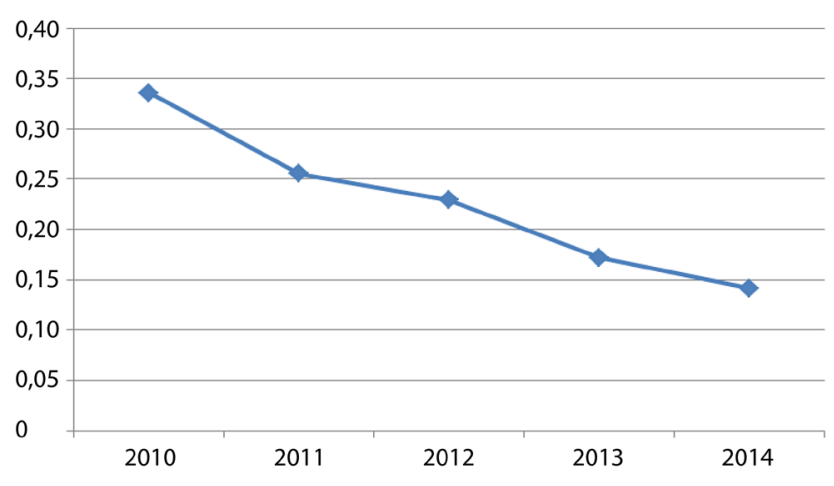

1. ábra $\mid$ Teammegbeszélés nélkül mútött esetek aránya a vizsgált években

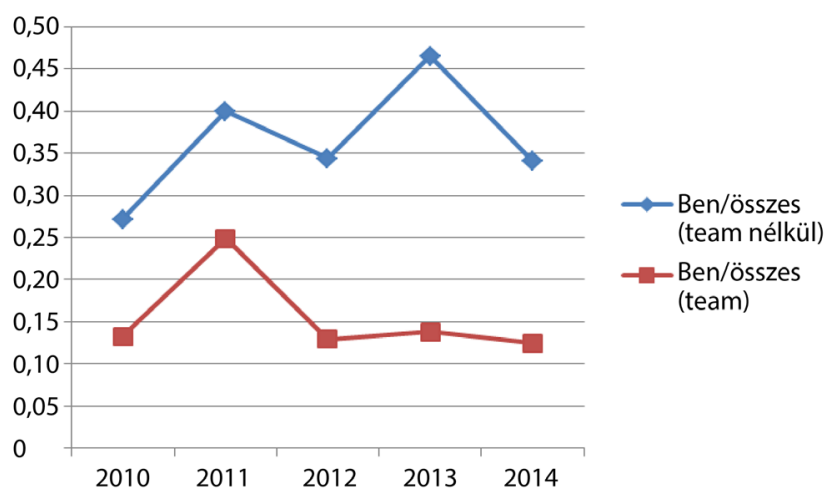

2. ábra

Emlőbizottság előtt megbeszélt és meg nem beszélt operált esetek benignus (Ben) aránya

irányuló mintavétel utáni emlóeset került multidiszciplináris megbeszélésen a Decker-féle rendszerben értékelésre. Ugyanezen periódus alatt 1342 esetben történt emlősebészeti beavatkozás. Értelemszerúen a periódus legelején operált esetek még nem a Decker-féle rendszerben kerültek preoperatív értékelésre. Ugyanakkor a periódus végén szereplő betegek diagnosztikáját lezáró beavatkozásokat figyelembe tudtuk venni akkor is, ha azok 2014 decembere után történtek.

A mútétek $23 \%$-a $(n=313)$ formális helyi emlóbizottsági megbeszélés nélkül történt, de ez az arány fokozatos csökkenést mutatott az öt év alatt, és az utolsó évben csak 16\% volt (1. ábra). Dokumentáltan legalább 114 esetben a betegek kivizsgálása máshol történt. A helyi emlőbizottság előtt nem tárgyalt (az esetek egy részében esetleg más emlőbizottság által véleményezett) rosszindulatú tumoros esetek aránya az egész periódus alatt átlagosan $18 \%$-os arányt $(192 / 1073)$ ért el; a 2000 -es 30\%-ról 2004-re 9\%-ra módosult. Az operált elváltozások benignus/malignus aránya nagyjából $1 / 4$ $(269 / 1073)$ volt, azaz a mútött elváltozások $20 \%$-a volt jóindulatú. A benignus mútétek aránya magasabb volt a team nélkül operált betegeknél (2. ábra).

Az esetek nagy része 5-ös, malignitásra jellemző OCIkategóriával került emlóbizottsági megbeszélésre (2. táblázat), és ezen esetek nagy része malignusnak is bizo- nyult a nonoperatív vagy operatív diagnosztika során. Javasolt mútétekkel további hét esetben $\mathrm{C} 4$ vagy $\mathrm{B} 4$, három esetben $\mathrm{B} 3$, illetve négy esetben $\mathrm{B} 1$ vagy $\mathrm{B} 2$ kategória mellett igazolódott malignitás vagy borderline phylloid tumor. Az utóbbi eseteknél, bár a hengerbiopszia nem igazolt malignitást, a klinikai kép, a korreláció hiánya vagy bizonytalansága, illetve az ezek alapján felállított A4 cselekvési kategória miatt (diagnosztikus) mútétre került sor, és az igazolta a malignitást (három betegnél invazív lobularis carcinomát, egynél nem speciális típusú emlőrákot). Megjegyzendő, hogy az egyik lobularis carcinoma Bl minősítésű biopsziáját $\mathrm{C} 4$ aspiráció is megelőzte. Az összesített klinikai benyomás csökkenő kategóriái mellett az elváltozások malignitási aránya is csökkent (2. táblázat). Malignitás még klinikailag benignusnak ítélt eltérések mellett is előfordult kis arányban: nyolc mintavétel felvetette malignitás lehetőségét (minden esetben C4), és ezek, valamint egy C3 értékelésú minta további feldolgozása kapcsán négy esetben igazoltunk rosszindulatú folyamatot hengerbiopsziával. Kis számban $(\mathrm{n}=8)$ előfordult 1 -es kategóriában is mintavétel. Ilyenkor nem volt a mintavételre alkalmas elváltozás a szokványos képalkotókkal, de a beteg vagy a gondozását végző onkológus kolléga megnyugtatására nem tudtunk kitérni MRI (mágneses rezonanciás képalkotás) által jelzett elváltozások helyén látott szabályos emlóállomány (nem MRI-vezérelt és ezért szakmailag kifogásolható, de indokolatlan) mintavételétól. Ezen esetekben elváltozást a mintavétel (és a követés) sem igazolt.

A mintavételek szerinti megoszlásból (3. táblázat) kiderül, hogy az esetek közel egy-egy harmadában citológia, illetve hengerbiopszia adta a végeredményt, és további egyharmadban mindkét mintavételre szükség volt vagy több együttes elváltozás egyidejű mintavétele miatt, vagy nem korreláló, nem diagnosztikus vagy terápiát lehetővé nem tevő citológiai mintavétel miatt (második lépésben). Az 5-ös kategóriájú, malignitást igazoló eredmények nagy része $(68,6 \%$-a) hengerbiopsziából származott. A mintavétel ismétlésére kivételesen került sor azonos módszerrel, 26 esetben ismételt citológiával és öt esetben ismételt pisztolyos hengerbiopsziával zárult a nonoperatív kivizsgálás.

2. táblázat |Az összegzett esetek megoszlása OCI-kategória szerint, a preoperatív mintavételek alapján malignus (C5/B5) és a mütéti diagnózisokat (amennyiben volt ilyen) is figyelembe vevő összes malignus esetek száma, aránya

\begin{tabular}{lccc}
\hline OCI-kategória & Esetszám (\%) & C5 vagy B5 (\%) & Malignus (\%) \\
\hline 1 & $8(0,5)$ & $0(0)$ & $0(0)$ \\
2 & $134(7,8)$ & $4(3)$ & $4(3)$ \\
3 & $440(25,6)$ & $78(17,7)$ & $89(20,2)$ \\
4 & $271(15,8)$ & $173(63,8)$ & $190(70,1)$ \\
5 & $863(50,3)$ & $825(95,6)$ & $839(97,2)$ \\
\hline Összesen & $1716(100)$ & $1080(62,9)$ & $1122(65,4)$ \\
\hline
\end{tabular}


3. táblázat |Az összegzett esetek megoszlása nonoperatív mintavétel végső eredménye alapján

\begin{tabular}{lcccccc|c}
\hline Mintavétel/kategória & 1 & 2 & 3 & 4 & 5 & Összesen \\
\hline $\mathrm{C}$ & 37 & 153 & 28 & 10 & 337 & $565(32,9 \%)$ \\
\hline reC & 4 & 14 & 3 & 2 & 3 & $26(1,5 \%)$ \\
\hline B & 27 & 78 & 24 & 1 & 412 & $542(31,6 \%)$ \\
\hline reB & 0 & 2 & 1 & 0 & 2 & $5(0,3 \%)$ \\
\hline C és B & 46 & 63 & $58 / 53^{*}$ & 30 & 328 & $578(33,7 \%)$ \\
\hline Összesen & $114(6,6 \%)$ & $310(18,1 \%)$ & $167(9,7 \%)$ & $43(2,5 \%)$ & $1082(63,1 \%)$ & 1716 \\
\hline
\end{tabular}

$\mathrm{B}=$ hengerbiopsziás mintavétel; $\mathrm{C}=$ citológiai mintavétel (általában aspiráció, ritkábban váladékcitológia); $\mathrm{C}$ és $\mathrm{B}=$ párhuzamos vagy egymást követő citológiai és hengerbiopsziás mintavétel; reB = ismételt hengerbiopsziás mintavétel; reC = ismételt citológiai mintavétel

*A C3 és B3 eredmények merôben eltérő volta miatt C3/B3 eredmények külön megadva.

4. táblázat |Az elemzett esetek A kategória szerinti megoszlása

\begin{tabular}{lccccccc}
\hline Jelleg/kategóriák & $\mathrm{Al}$ & $\mathrm{A} 2$ & $\mathrm{~A} 3$ & $\mathrm{~A} 4$ & A5 & Összesen \\
\hline Egy teamen & 42 & 278 & 45 & 54 & 866 & 1285 \\
\hline Ismételt teamen & 6 & 95 & 47 & 68 & 215 & 431 \\
\hline Összesen & 48 & 373 & 92 & 122 & 1081 & 1716 \\
\hline Mútve & $39(81,3 \%)$ & $65(17,4 \%)$ & $9(9,8 \%)$ & $109(89,3 \%)$ & $872(80,7 \%)^{*}$ & $1094(63,8 \%)$ \\
\hline Malignus (összesböl) & $3(6,3 \%)$ & $4(1,1 \%)$ & $2(2,2 \%)$ & $38(31,1 \%)$ & $1079(99,8 \%)$ & $1123(65,4 \%)$ \\
\hline
\end{tabular}

*Esetlegesen más helyen operált beteg miatt a mútéti arány ennél magasabb lehet.

Mind az értékelhetetlen/normális $(\mathrm{Cl} / \mathrm{Bl})$, mind pedig a malignitásra gyanús (39 C4, illetve négy B4) végleges eredmények ritkák voltak. Az utóbbiak esetén 26 alkalommal volt mútét, és ezek $3 / 4$ B4 és 10/22 C4 esetben igazoltak malignus (vagy borderline) tumort. A többi esetben a mútét következmény nélküli lett volna $(\mathrm{n}=2)$, fennálló korreláció mellett $\mathrm{B} 2$ vagy $\mathrm{B} 1$ mintavétel tisztázta az elváltozás lényegét $(\mathrm{n}=13)$, illetve bizonytalan korreláció mellett rövid távú követés (A3, $\mathrm{n}=2$ ) szólt a benignitás mellett.

A C3 és B3 kategóriák eltérő értelmúek, a hozzájuk társuló mútéti, illetve malignitási arány ezért külön indikátor lehet. A 89 C3 végeredményú mintavétel 31,5\%ában történt mútét, és ez az esetek 10,1\%-ában $(\mathrm{n}=9)$ igazolt malignitást, míg egy további betegnél atípusos ductalis hyperplasia $(\mathrm{ADH})$ lett a szövettani diagnózis. A 78 B3 végeredményú mintavétel $80,8 \%$-ban vezetett mútéthez, hat esetben malignitás, három esetben borderline phylloid tumor és egy esetben fibromatosis igazolódott, azaz 13,2\%-ban rosszindulatú vagy bizonytalan biológiai viselkedésû́ daganatok és további öt esetben $\mathrm{ADH}$, illetve egy esetben adenomyoepithelioma neoplasztikus elváltozások kerültek felismerésre; a fennmaradó laesiók jóindulatúnak bizonyultak.

A további teendők A kategóriája szerinti esetmegoszlást a 4. táblázat mutatja. Kitúnik, hogy az elváltozások nagy részét $(66,7 \%)$ azonnal igazolt malignitás révén terápiát lehetôvé tevő $\mathrm{A} 5$ vagy benignus diagnózis miatt rosszindulatú folyamat irányában további teendő́t nem igénylő A2 kategóriába lehetett sorolni. Ugyanakkor az esetek közel egynegyedében (akár többszörösen) ismételt teamen sikerült csak végleges A kategória szerinti besorolást elérni.

A preoperatív mintavétel malignitást igazoló volta mellett két esetben nem állt fenn malignitás (5. táblázat, 51. és 1284. eset): az egyiknél B5a in situ ductus carcinoma diagnózis született, mivel két szövethengerben is jelen volt a $2 \mathrm{~mm}$-t egyikben sem meghaladó jól differenciált neoplasztikus folyamat; ezek mindegyike csak atípusos ductalis típusú hámproliferációnak felelt volna meg önmagában (B3), de együttesen nagyobb kiterjedésre utaltak, és emiatt túlértékelésre kerültek. Az excíziós mintával együtt is csak $\mathrm{ADH}$ igazolódott. A másik esetben posztoperatív hegre jellemző képalkotó és fizikális lelet mellett, ezt igazoló hengerbiopsziás eredmény született, de az ellenoldali hónalj vizsgálata felvetette recidív tumor lehetőségét, amit a malignitást igazoló „C5” aspirációs citológiai lelet is megerősített; az elvégzett hónalji blokkdissectio anyagában áttét és háminclusio nélküli 12 nyirokcsomó került csak vizsgálatra. A tévesen azonosított vagy eredménytelenül vizsgált és ezért tanulságos eseteket az 5. táblázat foglalja össze.

Az előbbiekben leírt téves A5 minősítés mellett három téves A2 minősítés is külön említést igényel (5. táblázat, 450., 635. és 745. eset). Ezekben nem papillaris laesiók álltak fenn, és OCI3 klinikai besorolás és fennálló korre- 
5. táblázat |A Decker-rendszer alkalmazása ellenére is tévesen, késedelemmel vagy eredménytelenül azonosított esetek

\begin{tabular}{|c|c|c|c|c|c|c|c|c|c|}
\hline Sorszám & $\mathrm{R}$ & $\mathrm{K}$ & $\mathrm{U}$ & OCI & $\mathrm{C} / \mathrm{B}$ & Co & A & Rendben? & Megjegyzés \\
\hline 51. & 4 & 1 & 3 & 4 & $\mathrm{Cl} \rightarrow \mathrm{B} 5$ & $2 \rightarrow 1$ & $4 \rightarrow 5$ & $\mathrm{n} \rightarrow \mathrm{i}$ & $\begin{array}{l}\text { Két hengerben atípusos hám DCIS-ként (B5a) } \\
\text { túlértékelve; } \mathrm{ADH}\end{array}$ \\
\hline 249. & 3 & 3 & 3 & 3 & $\mathrm{C} 2, \mathrm{C} 3$ & 1 & 2 & $\mathrm{i}$ & Váladékozó ductus miatt SD, abban IDP ADH-val \\
\hline 364. & 3 & 3 & 1 & 3 & $\mathrm{C} 2$ & 1 & 2 & i & $\begin{array}{l}\text { Váladékozó ductus miatt SD, abban IDP LG } \\
\text { DCIS-sel }\end{array}$ \\
\hline 450 & 3 & 3 & 3 & 3 & $\mathrm{Bl} \rightarrow \mathrm{C} 2$ & $3 a \rightarrow 1$ & $1 \rightarrow 2$ & $\mathrm{n} \rightarrow \mathrm{i}$ & $\begin{array}{l}\text { Növekedés miatt eltávolított terime: infundibularis } \\
\text { (epidermoid) cisztából kiinduló jól differenciált } \\
\text { laphámrák }\end{array}$ \\
\hline 630. & 3 & 2 & 3 & 3 & $\mathrm{Cl} \rightarrow \mathrm{C} 2$ & $3 a \rightarrow 1$ & $1 \rightarrow 3 \rightarrow 3$ & $\mathrm{n} \rightarrow \mathrm{n} \rightarrow \mathrm{n}$ & $\begin{array}{l}\text { Követésre nem jött vissza a beteg, } 18 \text { hó múlva } \\
\text { R5K5U4 B5b: ILC }\end{array}$ \\
\hline 635. & 1 & 2 & 3 & 3 & $\mathrm{C} 2$ & 1 & 2 & i & $\begin{array}{l}\text { Két év kontroll helyett szûrés, } 35 \text { hó múlva R5K5U3 } \\
\text { B5b: NST (IDC) }\end{array}$ \\
\hline 745 . & 3 & 1 & 3 & 3 & $\mathrm{C} 2$ & 1 & 2 & $\mathrm{i}$ & 24 hó múlva R4KlU5 C4 $\rightarrow$ B5: ILC \\
\hline 904. & 2 & 3 & 2 & 3 & $\mathrm{C} 2$ & 1 & 2 & $\mathrm{i}$ & $\begin{array}{l}\text { Váladékozó ductus miatt SD, abban IDP, ebben, } \\
\text { illetve körülötte LG DCIS }\end{array}$ \\
\hline 965. & 4 & 1 & 4 & 4 & $\mathrm{C} 4$ & 1 & 4 & $\mathrm{n}$ & $\begin{array}{l}\text { Szürésből kiemelt, megajánlott hengerbiopsziát nem } \\
\text { fogadta el; } 46 \text { hó múlva jelentkezett: R5K5U5 C5: } \\
\text { NST (IDC) }\end{array}$ \\
\hline 1284. & 1 & 1 & 2 & $4^{*}$ & $\mathrm{~B} 2, \mathrm{C} 5 *$ & 1 & 5 & $\mathrm{i}$ & $\begin{array}{l}\text { Hamis pozitív citológia, a hónalji blokkban } 12 \\
\text { áttétmentes nyirokcsomó }\end{array}$ \\
\hline 1437. & 3 & 1 & 5 & 5 & $\mathrm{Cl} \rightarrow \mathrm{Bl}$ & $2 \rightarrow 3 \mathrm{a}$ & $4 \rightarrow 4 \rightarrow 3$ & $\mathrm{n} \rightarrow \mathrm{n} \rightarrow \mathrm{n}$ & $\begin{array}{l}\text { C1 és Bl alapján U5 revíziója U3-ra (OCI3), hat } \\
\text { hónapos követésen nem jelent meg; többszöri hívásra } \\
17 \text { hó múlva jelent meg: R5K5U5 B5b: NST (IDC) }\end{array}$ \\
\hline 1478. & 2 & 2 & 1 & 2 & C3 & 1 & 3 & $\mathrm{n} \rightarrow$ opus i & Váladékozó ductus miatt SD, papillaris DCIS \\
\hline 1513. & 5 & 3 & 5 & 5 & $\mathrm{Cl} \rightarrow \mathrm{Bl}$ & $2 \rightarrow 2$ & $4 \rightarrow 4$ & $\mathrm{n} \rightarrow \mathrm{n} \rightarrow \mathrm{opus} \mathrm{i}$ & $\begin{array}{l}\text { Nonoperatív diagnosztika nem vezetett eredményre; } \\
\text { mútét: NST (IDC) }\end{array}$ \\
\hline 1611. & 5 & 1 & 5 & 5 & $\mathrm{Cl} \rightarrow \mathrm{Bl}$ & $2 \rightarrow 2$ & $4 \rightarrow 4$ & $\mathrm{n} \rightarrow \mathrm{n} \rightarrow \mathrm{opus} \mathrm{i}$ & $\begin{array}{l}\text { Nonoperatív diagnosztika nem vezetett eredményre; } \\
\text { mütét: NST (IDC + EIC) }\end{array}$ \\
\hline
\end{tabular}

R, K, U, OCI, C, B, Co, A: A Decker-rendszer 1. táblázatban definiált kategóriái.

$\mathrm{ADH}=$ atípusos ductalis hámhyperplasia, DCIS = ductus carcinoma in situ; EIC = extenzív intraductalis komponens; i = igen; IDP = intraductalis papilloma; ILC = invazív lobularis carcinoma; LG = low grade (jól differenciált); $\mathrm{n}=\mathrm{nem}$; NST (IDC) = nem speciális típusú emlőrák (invazív ductus carcinoma); SD = szelektív ductectomia

*Contralateralis nyirokcsomó miatt.

láció mellett C2 eredmények születtek. Az epidermoid cystából kiinduló jól differenciált laphámrák gyakorlatilag felismerhetetlen a preoperatív mintákból, és ezért elkerülhetetlen hiba: csak a mütéti anyag egészének alapos tanulmányozása tette lehetővé a diagnózis felállítását. A másik két esetben viszont a megnyugtatóan lezárt esetek kettő, illetve három év múlva malignus eltéréssel kerültek kórismézésre és kezelésre.

Az 1716 eset közel 90\%-ában $(\mathrm{n}=1531)$ nonoperatív diagnosztika tisztázta az eseteket, beleértve a rövid távú követés (A3) eredményeit is, de 157 esetben, többnyire A4 kategória mellett, diagnosztikus jellegú mútétre volt szükség az elváltozás pontos kórisméjének felállításához. Két esetben a nonoperatív diagnosztika eredménytelen maradt (5. táblázat, 1513. és 1611. eset), és további 26 esetben az elváltozások tisztázása elmaradt és nem várható a betegek halála, eltúnése, további vizsgálatba bele nem egyezése, terápiás következmény hiánya miatt.

\section{Megbeszélés}

Az emlőrákszưrés célja a rosszindulatú daganatok minél koraibb stádiumban való felismerése, és ezáltal az emlőrák okozta halálozás csökkentése. Bár maga a szürés specializált radiológiai módszerekkel történik, a kiemelt elváltozások diagnózist, verifikációt igényelnek, és ezt minden korszerú ajánlás szerint multidiszciplináris módon kell megvalósítani. Az emlőmútéteket is minden esetben komplex emlővizsgálatnak kell megelőznie [7]. Sajnálatos módon számos esetben rosszindulatú elváltozások miatt operált betegek sem kerültek emlőbizottsági megbeszélésre, és az európai minőségi ajánlásban javasolt 90\%-os, mútét előtti teamen történő megbeszélés arányát csak az utolsó évben sikerült elérni [11]. A jóindulatú elváltozások a szúrés szempontjából nem indokolnak mútétet, de méretük alapján néha mégis el kell távolítani őket. 
Az emlősebészet egyik minőségi indikátora lehet az eltávolítást nyert elváltozások benignus/malignus aránya. Ez az arány a preoperatív diagnosztika megfeleló voltát is jelzi; megfelelő diagnosztikai teljesítmény mellett az arány alacsony kell, hogy legyen [12]. Húsz évvel ezelőtt eredményként írtuk le, hogy 1,7-ről 0,7-re csökkent. Jelen vizsgálati periódus alatt pedig ez az arány ennek közel harmada, 0,25 (a teameken megbeszélt esetek vonatkozásában 0,18 ) volt, ami jónak mondható. Az Országos Onkológiai Intézet (OOI) nemrégiben közölt adataiból arra lehet következtetni, hogy ott a benignus elváltozásokat eltávolító mütétek aránya még alacsonyabb (3,4\%), mintegy ötöde az itt leírtnak [13]. A jelentős különbség hátterében a populációk eltérô volta állhat, hiszen például az OOI anyagában mindössze 5/466 esetben fordult elő a gyakran mütétet indikáló és a papillaris laesiókat, atípusos hámproliferációkat, lobularis neoplasiát, cellularis fibroepithelialis laesiókat, szklerotizáló laesiókat és néhány egyéb, ritkább entitást magába foglaló B3 eredmény a hengerbiopsziák között! Az is megállapítható, hogy a team nélkül operált elváltozások között magasabb volt a jóindulatú elváltozások aránya, mint a helyi emlőbizottság előtt megbeszélt eseteknél (2. ábra). Mivel az okokat nem állt módunkban vizsgálni, nem tudni, hogy a különbség abból adódik-e, hogy a benignusnak tûnő elváltozások esetén a sebészek kevésbé éreznek késztetést a kimetszést megelőző komplex vizsgálatra, vagy hogy esetleg hozott, de a dokumentációban nem rögzített eredmények alapján operálták a betegeket. Az előbbi lehetőség hibák forrása lehet, de az utóbbi is eredményezhet téves beavatkozásokat! Bár onkológiai szempontból a benignus elváltozások sebészi eltávolítása nem cél, az emlőrákszürés kapcsán kiemelt egyes elváltozások mútétet igényelnek, és például a B3 kategóriájúak esetében legalább háromnegyedüknél a mütét benignus végső diagnózist eredményez. (A közleményben ezek az esetek is, mint diagnosztikus excisio, sebészi biopszia szerepelnek, hiszen a kórisme végleges tisztázása képezi a mútéti indikációt.)

A malignusnak tünő elváltozások, tünjenek malignusnak akár a radiológiai (mammográfiás és ultrahang), valamint fizikális vizsgálat (inspekció, tapintás) eredményeit összegző OCI-kategória alapján, akár a citológiai mintavétel alapján, nem minden esetben bizonyulnak malignusnak. Sőt bár a B5 kategóriát a rosszindulatúság bizonyítékaként fogadjuk el, a konzultációs gyakorlat alapján, kisebb tapasztalat mellett, ritkán előfordul túlértékelés, téves diagnózis. Jelen elemzésben is előfordult egy alkalommal, hogy atípusos ductalis hyperplasia a tóle minőségben nem, csak mennyiségben különböző jól differenciált (low grade) in situ ductus carcinomaként került értékelésre, mivel két szövethengerben is benne volt az elváltozás (5. táblázat, 51. eset). A benignitással hasonló a helyzet. Klinikailag jóindulatúnak túnő eltérések malignusnak bizonyulhatnak, és benignitás mellett szóló mintavételek is lehetnek tévesek, például a nem megfelelő helyről vett minták vagy alacsony sejtdenzitású lobula- ris rákok esetén. Emiatt a leleteket soha sem szabad önmagukban értékelni [7], és ezért van alapja annak az ajánlásnak, hogy az elváltozásokat multidiszciplináris közegben kell kiértékelni, és így kell dönteni a további diagnosztikus vagy terápiás lépésről.

Mivel jelen elemzés egy terápia előtti emlőbizottság múködését mutatja be, az A5 végkimenetel csak a malignus laesiónak megfelelő terápiás döntés lehetőségéig terjed. Ezt követően a tumor anatómiai és biológiai paraméterei és a beteg állapota alapján történik a legmegfelelőbb kezelés kiválasztása [14-16], és ez nem témája a jelen közleménynek. A radiológiai/klinikai kép és a mikroszkópos vizsgálat eredményének korreláltatása a multidiszciplináris megközelítésnek alapvető eleme, és az eredmények csak akkor fogadhatók el, ha egymásnak megfelelnek, összhangban vannak $[7,17,18]$. Ezt minden emlőbizottság figyelembe veszi, ugyanakkor a Decker-féle rendszer ezt a korreláltatást kategóriába sorolva, retrospektív elemzésre is alkalmas módon, követhetően teszi meg. Az OCI és C és/vagy B kategóriák együttes elemzése vagy egymásnak megfeleltetése (Co kategória) lehetővé teszi az A kategóriákkal tükrözött, megfelelő teendők tervezését is.

Szabályos szövet vagy benignus eltérés mikroszkópos értékelése esetén, fennálló korrelációval az eset a szürési protokoll szerinti követést igényli (szürési korcsoportban kétévente történő meghívást). Ugyanilyen mikroszkópos értékelés mellett, ha a korreláció nem áll fenn, vagy ha a mikroszkópos eredmény bizonytalan malignitási potenciált (B3) vagy malignitási gyanút (B4) véleményez, ismételt mintavétel (hengerbiopszia, vákuumaszszisztált hengerbiopszia vagy excisio) indokolt a korrelációtól függetlenül. A malignitást igazoló B5 kategóriájú minták a korrelációtól függetlenül lehetővé teszik a terápiás döntést [8]. Tekintettel arra, hogy kórházunkban aspirációs és/vagy váladékcitológia is gyakran történik, lényeges volt az így kapott eredményekkel kapcsolatosan is állást foglalni. A Cl-esetek nem tekinthetők diagnosztikusnak. A C2-, C4- és C5-esetek lényegében az azonos B kategóriáknak megfelelő értékeléssel vehetők figyelembe, míg a C3 vagy ismételt mintavételt, vagy követést igényel, az OCI és a Co kategóriák függvényében.

Az OCI, C/B és Co kategóriák viszonyát legjobban a malignitásra klinikailag valamennyire gyanús (OCI4) eltérések esetén kapott B2 eredmény szemlélteti, ahol a Co függvénye, hogy mit kell csinálni az elváltozással. Korreláció esetén a B2 eredmény alapján szokványos követés javasolható (A2), bizonytalan, de valószínú korrelációval a személyt nem szabad elengedni, mert a bizonytalanság rövid távú kontrollt igényel (A3), míg a korreláció hiánya, valószínútlensége pedig ismételt mintavételt indokol (A4).

Az európai ajánlások értelmében malignus daganatként csak a biztonsággal annak diagnosztizált elváltozások kezelhetők, azaz a malignitásra gyanús ( $\mathrm{C} 4$ vagy $\mathrm{B} 4$ kategóriájú) elváltozásokról előbb igazolni kell, hogy rosszindulatúak $[7,17]$. Bár korábban azt a gyakorlatot 
követtük, hogy ha minden más 5-ös kategóriába esett, akkor igyekeztünk malignus elváltozásként kezelni a laesiót $[19,20]$, a vizsgált öt évben az ilyen 4-es, malignitás diagnózisát lehetővé nem tevő mikroszkópos vélemény esetén diagnosztikus kimetszések történtek. Az OCI5 kategória melletti $\mathrm{C} 4$ vagy $\mathrm{B} 4$ végeredményü laesiók mind malignusak lettek, azaz nem cáfolják a korábbi megközelítésünket, amely szerint ilyenkor megengedhetőnek tünik a terápiás sebészi beavatkozás. Összességükben a C4-es elváltozások sokkal alacsonyabb arányban bizonyultak malignusnak, mint a lényegesen kisebb számban előforduló B4-es esetek.

A legjobb szándék és együttmúködés mellett is előfordulnak hibák a rendszerben. Az eredmények között részletezett két fals pozitív (A5) és három hamis negatív (A2) eset mellett két esetben például ismételt mintavétellel sem lehetett preoperatív diagnózishoz jutni, ami miatt diagnosztikus célú kimetszésre kellett sort keríteni (5. táblázat utolsó két sora). Az intraductalis papillomákkal összefüggésben kialakuló, általában jól differenciált (low grade) neoplasztikus folyamatokat $(\mathrm{ADH}$, DCIS) több esetben nem ismertük fel a preoperatív megközelítésben (5. táblázat, 249., 364., 904., 1478. eset), ami összhangban van korábbi tapasztalatunkkal [21]. Az egy járatból gyakran véresen váladékozó, és emiatt panaszt okozó, az esetek nagy részében papillomának megfelelő elváltozásokat kórházunkban minimális sebészi eljárással, szelektív ductectomiával távolítják el, és ez a panaszokat is megszünteti. Ilyenkor viszonylag gyakran (16\%) neoplasztikus laesio is felismerésre kerül, bár kétségtelen, hogy az esetek háromnegyedében low grade neoplasia (DCIS, ADH, lobularis neoplasia) állt fenn, és ennek a mütétet igénylő volta vita tárgyát képezi; két jelenleg futó klinikai vizsgálat is igyekszik tisztázni, hogy érintetlenül hagyhatók-e az ilyen laesiók [22, 23]. Amint az kiderül az 5. táblázatból, néhány beteg (630., 635., 965. és 1437.) nem tartotta a rövid követési javaslatot, illetve nem egyezett bele a mintavételbe. Az eltelt idő alatt elváltozásaikról malignitás igazolódott, de a korai diagnózis elmaradt. Az ilyen esetek kiszűrésére a megnyugtatóan le nem zárt esetek rendszeres kiemelése, visszahívása segíthet, de ha a vizsgált személy elzárkózik a felkínált lehetőségektől, akkor sajnos továbbra is lesznek késéssel felismert emlőrákos esetek a vizsgáltak körében. A motiváltság a felfedezett eltérések tisztázására lényeges és szorgalmazandó [24].

\section{Következtetés}

Megállapítjuk, hogy a Decker-féle rendszer alkalmas arra, hogy a preterápiás multidiszciplináris emlőbizottságon a kiemelt emlőelváltozások radio-(kliniko-)patológiai korrelációját rögzítsük vele, és hasonlóan, elemzésre alkalmas módon a további diagnosztikus teendóket (vagy azok szükségtelenségét, a definitív kezelés lehetőségét) is kódoljuk vele. A rendszer alkalmazása lehetővé teszi azt is, hogy a diagnosztikus szempontból megnyugtatóan le nem zárt esetek ne kerüljenek ki a látókörből.

Anyagi támogatás: A dolgozatot részben a Nemzeti Kutatási, Fejlesztési és Innovációs Hivatal GINOP-2.3.215-2016-00020 számú pályázata támogatta.

Szerzői munkamegosztás: Cs. G.: Koncepció, adatgyüjtés, irodalomkutatás, a kézirat első változatának megszövegezése, végleges formába öntése, jóváhagyása. A. É., S. O.: Adatgyújtés, a kézirat végleges formájának kialakítása, jóváhagyása. A cikk végleges változatát mindhárom szerző elolvasta és jóváhagyta.

Érdekeltségek: A szerzőknek nincsenek érdekeltségeik.

\section{Köszönetnyilvánítás}

A szerzők ezúton mondanak köszönetet $d r$. Hajnal-Papp Rozáliának, dr. Lóránd Katalinnak, dr. Maráz Róbertnek, dr. Markó Lászlónak, dr. Pajkos Gábornak, dr. Rácz Andrásnak, dr. Serényi Péternek és Febérné Horváth Margitnak, az „emlőteam” állandó tagjainak, akik napi munkájukkal hozzájárultak a multidiszciplináris értékelés folyamatához, de nem vettek részt az adatok szisztémás gyújtésében és elemzésében, a team múködésének értékelésében.

\section{Irodalom}

[1] Kásler M, Ottó Sz, Kenessey I. The current situation of cancer morbidity and mortality in the light of the National Cancer Registry, Hungary. [A rákmorbiditás és -mortalitás jelenlegi helyzete a Nemzeti Rákregiszter tükrében.] Orv Hetil. 2017; 158: 8489. [Hungarian]

[2] Tabár L, Vitak B, Chen TH, et al. Swedish two-county trial: impact of mammographic screening on breast cancer mortality during 3 decades. Radiology 2011; 260: 658-663.

[3] Njor S, Nyström L, Moss S, et al. Breast cancer mortality in mammographic screening in Europe: a review of incidence-based mortality studies. J Med Screen. 2012; 19(Suppl 1): 33-41.

[4] Forrai G, Ambrózay É, Bidlek M, et al. Use of imaging methods in the current screening, diagnostics and treatment of breast cancer - Professional guidelines. 3rd Breast Cancer Consensus Meeting. [A képalkotó vizsgálómódszerek alkalmazása az emlődaganatok korszerű szűrésében, diagnosztikájában és ellátásában - Szakmai útmutató a III. Emlőrák Konszenzus Konferencia alapján.] Magy Onkol. 2016; 60: 181-193. [Hungarian]

[5] Boncz I, Döbróssy L, Péntek Z, et al. Attendance of the fourth (2008-2009) screening round of the Hungarian organized, nationwide breast cancer screening program. [A szervezett országos emlőszűrési program negyedik (2008-2009) szűrési körének részvételi arányai.] Orv Hetil. 2013; 154: 1975-1983. [Hungarian]

[6] Döbrőssy L. (ed.) Organized screening in oncology - a quality assurance handbook and methodological guideline. [Szervezett szưrés az onkológiában - Minőségbiztosítási kézikönyv és módszertani útmutató.] Ministry of Health [Egészségügyi Minisztérium], Budapest, 2000. [Hungarian]

[7] Cserni G, Kulka J, Francz M, et al. Pathological diagnosis, workup and reporting of breast cancer. Recommendations of the 3rd Hungarian Consensus Conference on Breast Cancer. [Az emlőrák patológiai diagnosztikája, feldolgozása és kórszövettani 
leletezése. Szakmai útmutatás a III. Emlőrák Konszenzus Konferencia alapján.] Magy Onkol. 2016; 60: 209-228. [Hun garian]

[8] Decker T, Boecker W, Kettritz U, et al. Pathological diagnosis in minimal invasive biopsy. In: Boecker W. (ed) Preneoplasia of the breast: A new conceptual approach to proliferative breast disease. Elsevier GmbH, Munich, 2006; pp. 81-106.

[9] Cserni G, Mátrai Z, Bak M. Multidisciplinary approach to breast cancer. In: Mátrai Z, Gulyás G, Kásler M. (eds.) Contemporary surgery of breast cancer. [Az emlőrákok multidiszciplináris megközelítése. In: Mátrai Z, Gulyás G, Kásler M. (szerk.): Az emlőrák korszerú sebészete.] Medicina Könyvkiadó, Budapest, 2015; pp. 101-110. [Hungarian]

[10] Zakhour H, Well CA. Fibrocystic change of the breast. In: Zakhour H, Wells CA. (eds.) Diagnostic cytopathology of the breast. Churchill-Livingstone, London, 1999; pp. 95-101.

[11] Rosselli Del Turco M, Ponti A, Blick U, et al. Quality indicators in breast cancer care. Eur J Cancer 2010; 46: 2344-2356.

[12] Cserni G. Changes in benign to malignant ratio of surgically treated breast diseases in a district hospital. Pathol Oncol Res. 1997; 3: 109-114.

[13] Újhelyi M, Pukancsik D, Kelemen P, et al. Breast cancer care quality analysis of the National Institute of Oncology in Hungary according to the requirements of European Society of Breast Cancer Specialists (EUSOMA). [A European Society of Breast Cancer Specialists (EUSOMA) eloórásainak megfeleló emlőrákellátás minőségbiztosítási elemzése az Országos Onkológiai Intézetben.] Orv Hetil. 2016; 157: 1674-1682. [Hungarian]

[14] Lázár Gy, Bursics A, Farsang Z, et al. 3rd Hungarian Breast Cancer Consensus Conference - Surgery guidelines. [III. Emlőrák Konszenzus Konferencia - Az emlőrák korszerú sebészi kezelése.] Magy Onkol. 2016; 60: 194-207. [Hungarian]

[15] Polgár Cs, Kahán Zs, Csejtei A, et al. 3rd Hungarian Breast Cancer Consensus Conference - Radiotherapy guidelines. [III. Emlőrák Konszenzus Konferencia - Sugárterápiás irányelvek.] Magy Onkol. 2016; 60: 229-239. [Hungarian]

[16] Horváth Zs, Boér K, Dank M, et al. Systemic therapy of breast cancer: practice guideline. [Az emlőrák szisztémás kezelése: szakmai útmutatás.] Magy Onkol. 2016; 60: 241-257. [Hungarian]

[17] Wells CA (ed.), Amendoeira I, Apostolikas N, et al. Quality assurance guidelines for pathology. In: Perry N, Broeders $M$, de Wolf C, et al. (eds.) European guidelines for quality assurance in breast cancer screening and diagnosis. Fourth edition. European Commission, Luxembourg, 2006; pp. 219-311.

[18] Wells CA (ed.), Amendoeira I, Bellocq JP, et al. S2: Pathology update. Quality assurance guidelines for pathology. In: Perry N, Broeders M, de Wolf C, et al. (eds.) European guidelines for quality assurance in breast cancer screening and diagnosis. Fourth edition - Supplements. European Commission, Office for Official Publications of the European Union, Luxembourg, 2012; 73-120.

[19] Ambrózay É, Bori R, Lơrincz M, et al. Breast core needle biopsies yielding uncertain results - Experience at the complex mammographic screening unit in Kecskemét. [Bizonytalan kategóriájú emlő-hengerbiopsziák és következményük - A kecskeméti komplex mammográfiás központ tapasztalatai.] Magy Radiol. 2005; 79: 184-192. [Hungarian]

[20] Cserni G, Ambrózay É, Serényi P, et al. Results of non-operative pathological breast diagnostics - One year experience at the Bács-Kiskun County Teaching Hospital. [A non-operatív patológiai diagnosztika eredményei az emlődiagnosztikában. A BácsKiskun Megyei Önkormányzat Kórházának egyéves tapasztalatai.] Magy Radiol. 2005; 79: 178-183. [Hungarian]

[21] Maráz R, Boross G, Ambrózay É, et al. Selective ductectomy for the diagnosis and treatment of intraductal papillary lesions presenting with single duct discharge. Pathol Oncol Res. 2013; 19 : 589-595.

[22] Elshof LE, Tryfonidis K, Slaets L, et al. Feasibility of a prospective, randomised, open-label, international multicentre, phase III, non-inferiority trial to assess the safety of active surveillance for low risk ductal carcinoma in situ - The LORD study. Eur J Cancer 2015; 51: 1497-1510.

[23] Francis A, Thomas J, Fallowfield L, et al. Addressing overtreatment of screen detected DCIS; the LORIS trial. Eur J Cancer 2015; 51: 2296-2303.

[24] Döbrőssy L, Cornides Á. European Code against Cancer: 12 ways to reduce your cancer risk. [Európai Rákellenes Kódex: 12 lehetőség, hogy csökkentse a rák kialakulásának kockázatát.] Orv Hetil. 2016; 157: 451-460. [Hungarian]

(Cserni Gábor dr., Kecskemét, Nyíri út 38., 6000 e-mail: cserni@freemail.hu) 